\title{
Persistence of PSB-Fungi Biofilmed Biofertilizer in the Soils and its Effect on Growth and Yield of Maize
}

\author{
S. Vinod Babu ${ }^{1 *}$, S. Triveni ${ }^{1}$, R. Subhash Reddy ${ }^{1}$ and J. Sathyanarayana ${ }^{2}$ \\ ${ }^{1}$ Department of Agricultural Microbiology and Bioenergy, ${ }^{2}$ Department of Entomology, College \\ of Agriculture, Professor Jayashankar Telangana State Agriculture University, \\ Rajendranagar, Telangana, India \\ *Corresponding author
}

\section{A B S T R A C T}

\section{Keywords}

Maize, Phosphate solubilising biofertilizer and Biofilm.

\section{Article Info}

Accepted:

15 October 2017

Available Online:

10 December 2017
Maize is grown throughout the year in India during kharif crop. Nitrogen and phosphorus are essential nutrients for plant growth and development in corn. Twenty four (24) phosphate solubilizing bacteria (i.e., sixteen Bacillus and eight Pseudomonas) were isolated from Maize Research Station and college farm, Rajendranagar, PJTSAU, Telangana. Persistency of Phosphate solubilizing biofertilizers in soil was recorded at different growth stages viz., vegetative, flowering and harvesting stage. There was an increasing trend observed from the vegetative to flowering stages and also a gradual decrease was observed from flowering stage towards harvesting stage. Similar trend was observed for all the treatments studied. But significantly higher were recorded in the treatment $\mathrm{T}_{7}$ - Carrier + Liquid + Biofilmed PSB biofertilizer at vegetative $\left(22.40 \times 10^{7} \mathrm{cfu}\right.$ $\left.\mathrm{g}^{-1}\right)$, flowering $\left(26.60 \times 10^{7} \mathrm{cfu} \mathrm{g}^{-1}\right)$ and at harvesting $\left(22.03 \times 10^{7} \mathrm{cfu} \mathrm{\textrm {g } ^ { - 1 }}\right)$ stage. The major outcome of this study was the Carrier + Liquid + Biofilmed PSB biofertilizer treated Maize (Zea mays) plants showed best performance for all the biological parameters measured than untreated and individual cultures.

\section{Introduction}

The phosphorus is present mostly insoluble form in the soil and it is unavailable to plants. Nitrogen fixing and $\mathrm{P}$ solubilizing bacteria are important for plant nutrition by increasing $\mathrm{N}$ and $\mathrm{P}$ uptake by the plants and playing a significant role as a Plant Growth Promoting Rhizobacteria (PGPR). Nitrogen fixation and $\mathrm{P}$ solubilization (Zaidi et al., 2006), production of antibiotics (Zahir et al., 2004) are the principal mechanism for PGPR.

Beneficial biofilms developed by nitrogen fixing bacteria and $\mathrm{P}$ - solubilising fungi in vitro conditions and also used as biofertilizers in non - leguminous crops and also observed that the bacteria colonized fungal mycelia to form biofilms. The biofilms showed high rates of biological nitrogen fixation and organic acid production which directly influences the synthesis of indole acetic acid like substances than microbes when used as monocultures (Seneiviratne et al., 2003). Nitrogen fixers play a key role in growth and persistence of effective microbial communities by supplying nitrogen through biological nitrogen fixation. This has been demonstrated in a number of studies, including reports on increased microbial 
efficiency of $\mathrm{P}$ solubilization, when the $\mathrm{N}$ source was added to naturally occurring, surface attached microbial communities or biofilms (Singh and Amberger, 1998). The present investigation continued on mainly collection of phosphate solubilizing microorganisms from different maize rhizosphere soils and commercial PSB inoculants. Preparing the different types (carrier, liquid and biofilmed) of biofertilizer formulations and test the efficacy and persistence of biofilmed based PSB and other types of biofertilizers with Maize crop are important.

\section{Materials and Methods}

\section{Collection of rhizosphere soil}

Rhizosphere soil samples were collected from Maize Research Station, Hyderabad and College Farm, College of Agriculture, Rajendranagar, Hyderabad.

\section{Preparation of biofilm with phosphate} solubilizing bacteria or fungi

\section{Compatibility studies}

Attempts were made study the compatibility between the PS bacteria and fungi. In this study compatibility of isolates selected with Aspergillus spp was investigated in vitro using the Perpendicular streak assay. The efficient isolates were selected and streaked on 4 sides of Aspergillus spp inoculated in the centre of the plates and the compatibility was recorded after incubation.

\section{Protocol for biofilm formation}

The above screened best phosphate solubilizing bacteria were selected for biofilm formation. A biofilm is an aggregate of microorganisms in which cells are struck to each other and/or to a surface. Pseudomonas spp/Bacillus spp + Aspergillus spp biofilm were prepared in nutrient agar medium. The inocula used for the preparation of different biofilms were five days old culture of fungi ( 3 $\mathrm{ml}$ ) and two days old culture of bacteria (5 $\mathrm{ml}$ ) in $250 \mathrm{ml}$ broth. Three sets of each for all the biofilms were prepared.

Initially $5 \mathrm{ml}$ of the bacterial culture was inoculated and then incubated for one day in a shaking incubator at $110 \mathrm{rpm}$ and then inoculation of Aspergillus spp $(5 \mathrm{ml})$. The flasks were incubated under static conditions at $30^{\circ} \mathrm{C}$ for 16 days until a thick film of culture was observed on the surface of the liquid medium.

The growth of the biofilm was observed for every two days interval. The progressive growth of biofilm was observed under microscope. The population counts were done using serial dilution - plate count method. After 16 days incubation the biofilm was harvested and washed repeatedly with sterile water for 2 - 3 times to remove the nonadherent cells from biofilm, then centrifuged and vortexed on a cyclomixer for $10 \mathrm{~min}$, with the use of sterilized glass beads to make it as a uniform suspension. The biofilm is a liquid suspension which was ready to apply under field conditions and also for taking the population counts, fresh weights and dry weights $\left(65^{\circ} \mathrm{C}\right.$ oven dried for $\left.24 \mathrm{~h}\right)$.

Assessing the persistence of the efficient PSB with maize crop in pot culture

The persistence of phosphate solubilising bacteria with different formulations viz., carrier, liquid and biofilmed biofertilizers was studied by pot culture.

\section{Location of the experiment}

A pot culture experiment was carried out in the Dept. of Agricultural Microbiology and Bioenergy, College of Agriculture, PJTSAU, Rajendranagar, Hyderabad. 


\section{Preparation of pots}

The soil from the college farm was collected and used for the pot culture studies. Each pot contains $8 \mathrm{kgs}$ soil.

\section{Design and Layout}

The pot culture experiment was conducted by following the Complete Randomized Block Design (CRD) with 8 treatments replicated thrice. Each pot measured $25 \mathrm{~cm} \times 25 \mathrm{~cm}$.

Details of the treatments used in the pot culture experiment

Location of Experiment: Department of Agriculture Microbiology and Bioenergy, College of Agriculture, Rajendranagar.

Crop: Maize

Variety: DHM - 117

Duration: 90 days

Season: Rabi-2015

Biofertilizers: Phosphate Solubilizing Bacteria (PSB)

Treatments: 8

Replications: 3

Design: CRD (Completely Randomized Design)

RDF (Recommended dose of fertilizer): 240: 80: $80 @ \mathrm{~kg} / \mathrm{ha}(\mathrm{N}: \mathrm{P}: \mathrm{K})$

\section{Treatments}

$\mathrm{T}_{0}: \operatorname{RDF}$ (240: 80: 80 @ kg/ ha)

$\mathrm{T}_{1}$ : Carrier based PSB biofertilizer
$\mathrm{T}_{2}$ : Liquid PSB biofertilizer

$\mathrm{T}_{3}$ : Biofilmed PSB biofertilizer

$\mathrm{T}_{4}$ : Carrier based PSB biofertilizer + Liquid PSB biofertilizer

$\mathrm{T}_{5}$ : Carrier based PSB + Biofilmed PSB biofertilizer

$\mathrm{T}_{6}$ : Liquid PSB biofertilizer + Biofilmed PSB biofertilizer

$\mathrm{T}_{7}$ : Carrier + liquid + Biofilmed PSB biofertilizer

\section{Seed germination with water agar}

Maize seeds (Variety DHM-117) were surface sterilised by $70 \%$ ethanol for $30 \mathrm{sec}$, followed by $0.1 \%$ mercuric chloride for $3 \mathrm{~min}$ and then rinsed the seeds several times with sterile distilled water. These seeds were air dried in laminar flow chamber.

The germination percent of seeds was tested by keeping the surface sterilised seed on 0.8 $\%$ water agar for $48 \mathrm{~h}$ with different coinoculants and biofilms.

Microbial counts at different intervals (30, 60, 90 DAS)

Microbial counts were recorded by the serial dilution and spread plate method at different crop growth stages (30, 60, 90 DAS)

\section{Results and Discussion}

\section{Compatibility study of bacteria with fungi which produced biofilms}

Compatability was studied among all Bacillus and Pseudomonas isolates with Aspergillus fungal isolate. The best compatality was observed with PSB 6 and Asp 1. (Plate 1) 


\section{Biofilms preparation and development}

The conditions were provided for in vitro development of biofilm for 12 days in Pikovaskaya broth with the efficient isolates (PSB 6 and Aspergillus spp). Biofilm mats were developed with PSB 6 and Aspergillus spp combination. (Plate 1)

Similar results were reported by Triveni et al., (2015) who prepared Trichoderma based biofilms with Aztobacter chroococcum, $P$. fluorescens and B. subtilis. While A. torulosa biofilms were prepared by using B. subtilis and Trichoderma.

Attempts were made by Nissipaul et al., (2014) to improve the crop production and disease control in chickpea by using Biofilm. The results revealed that $\mathrm{T}_{8}-T$. viride $+R$. leguminosarum $+P$. fluorescence $+B$. subtilis (Biofilm) showed best results for Biofilm formation followed by $\mathrm{T}_{2}$ Trichoderma viride + Rhizobium leguminosarum- Biofilm. Prasanna et al., (2014) developed carrier based cyanobacterial formulations and biofilmed inoculants for leguminous crops. Selected cyanobacterial strains were Anabaena laxaRP8 and Calothrix spp with Trichoderma.

\section{Efficiency and persistence of different} types of Phosphate solubilizing biofilmed with Maize crop in pot culture

Different types of phosphate solubilizing biofilms developed in vitro and other biofertilizers were applied in pot culture to study their efficiency and persistency. The microbial counts were taken at different growth intervals. It was found that the crop growth period influences the microbial population during vegetative and flowering stage due to availability of nutrients to microbes by the root exudation.

\section{Germination percentage}

The highest percentage of germination was observed in $\mathrm{T}_{7}$ - Carrier + liquid + biofilmed PSB biofertilizer i.e., $99.00 \%$. Lowest germination percentage was recorded in both $\mathrm{T}_{1}$ - Carrier based PSB biofertilizer and $\mathrm{T}_{2}$ Liquid PSB biofertilizer i.e., (93.56 \%). (Table 1).

Dicho and Verma (2014) inoculated Maize seeds by dipping in single solution of each bacterium containing $10^{8} \mathrm{cfu} \mathrm{\textrm {ml } ^ { - 1 }}$ and the control seeds were dipped in sterilized water. The highest germination percentage was obtained from seed inoculated with Azospirillum spp. This treatment had also best root length. The maximum height of plants was observed with seeds treated with Pseudomonas spp 1 with an increase of 69.85 percent. The highest shoot and root dry biomass were also recorded with Pseudomonas spp 1 (florescent) with an increase of 64.67percent and 49.67 percent respectively as compared to control. These results suggested that specific combinations of PGPR can be considered as efficient alternative biofertilizers to promote maize seed germination, biomass and crop yield.

\section{Initial population counts of bacteria and fungi in biofilms and individual cultures}

Initial population of total bacteria (PSB6) and fungi in $\mathrm{T}_{1}$ (Carrier based PSB biofertilizer) was $5.80 \times 10^{7}$ (bacterial population), $\mathrm{T}_{2}$ (Liquid PSB biofertilizer) $6.00 \times 10^{7}$ (bacterial population), $\mathrm{T}_{3}$ (Biofilmed PSB biofertilizer) $6.50 \times 10^{7}$ (bacterial population) and $5.61 \times 10^{4}$ (fungal population), $\mathrm{T}_{4}$ (Carrier based PSB biofertilizer + Liquid PSB biofertilizer) $4.50 \times 10^{7}$ (bacterial population), $\mathrm{T}_{5}$ (Carrier based PSB biofertilizer + Biofilmed PSB biofertilizer) $7.40 \times 10^{7}$ (bacterial population) and $4.60 \times 10^{4}$ (fungal population), $\mathrm{T}_{6}$ (Liquid PSB biofertilizer + 
Biofilmed PSB biofertilizer) $7.80 \times 10^{7}$ (bacterial population) and $5.24 \times 10^{4}$ (fungal population), $\mathrm{T}_{7}$ (Carrier + Liquid + Biofilmed PSB biofertilizer) $9.00 \times 10^{7}$ (bacterial population) and $5.80 \times 10^{4}$ fungal population (Table 1).

Population of bacteria and fungi at different intervals of crop growth period (30, 60, 90 DAS)

The data regarding population and persistency of different types PSB biofertilizers at different stages of crop growth was mentioned in Table 2 and plate 2 .

Bacterial and fungal population of seeds treated with phosphate solubilizing biofertilizer (in cfu $\mathrm{g}^{-1}$ ) (in cfu $\mathrm{g}^{-1}$ )

There was an increase in population upto the 60 DAS and there was a decrease in microbial population at 90 DAS. At 30 DAS highest bacterial population was observed in $T_{7}-$ Carrier + Liquid + Biofilmed PSB biofertilizer $\left(22.40 \times 10^{7}\right)$. The lowest bacterial population was recorded inT $_{4}$ Carrier based PSB biofertilizer + Liquid PSB biofertilizer $\left(9.86 \times 10^{7}\right)$.

After 30 days of sowing bacterial population compared to the initial culture population was recorded in $\mathrm{T}_{7}$ - Carrier + Liquid + Biofilmed PSB biofertilizer $(82.22 \%)$. The lowest bacterial population was observed in $T_{1}$ Carrier based PSB biofertilizer $(52.00$ percent).

At 60 DAS highest bacterial population was observed in $\mathrm{T}_{7}-$ Carrier + Liquid + Biofilmed PSB biofertilizer $\left(26.60 \times 10^{7}\right)$. The lowest bacterial population was observed in $_{4^{-}}$ Carrier based PSB biofertilizer + Liquid PSB biofertilizer $\left(10.20 \times 10^{7}\right)$.

Table.1 Effect of different phosphate solubilizing biofertilizers on germination percentage of maize seeds and initial population counts of bacteria and fungi in biofilms and individual cultures

\begin{tabular}{|c|c|c|c|}
\hline Treatments & $\begin{array}{c}\text { Germination } \\
\text { percentage }(\%)\end{array}$ & Bacteria x 10 $\mathbf{c f u ~ m l}^{-1}$ & Fungi x 10 $^{\mathbf{4}} \mathbf{c f u ~ m l}^{\mathbf{1}}$ \\
\hline Control & 92.12 & - & - \\
\hline $\mathrm{T}_{1}$ & 93.56 & 5.80 & - \\
\hline $\mathrm{T}_{2}$ & 93.56 & 6.00 & 5.61 \\
\hline $\mathrm{T}_{3}$ & 96.31 & 6.50 & - \\
\hline $\mathrm{T}_{4}$ & 95.73 & 4.50 & 4.60 \\
\hline $\mathrm{T}_{5}$ & 97.12 & 7.40 & 5.24 \\
\hline $\mathrm{T}_{6}$ & 98.46 & 7.80 & 5.80 \\
\hline $\mathrm{T}_{7}$ & 99.00 & 9.00 & \\
\hline
\end{tabular}

Treatments:

$\mathrm{T}_{1}$ : PSB 6 Carrier based PSB biofertilizer.

$\mathrm{T}_{2}$ : PSB 6 Liquid PSB biofertilizer.

$\mathrm{T}_{3}$ : Biofilmed PSB biofertilizer (PSB $6+$ Asp1).

$\mathrm{T}_{4}$ : PSB 6 Carrier based PSB biofertilizer + PSB6 Liquid PSB biofertilizer.

$\mathrm{T}_{5}$ : PSB 6 Carrier based PSB biofertilizer + Biofilmed PSB biofertilizer.

$\mathrm{T}_{6}$ : PSB 6Liquid PSB biofertilizer + Biofilmed PSB biofertilizer.

$\mathrm{T}_{7}$ : PSB 6 Carrier + PSB 6 Liquid + Biofilmed PSB biofertilizer. 
Table.2 Persistency of population counts of bacteria and fungi at 30, 60, 90 DAS (cfu g ${ }^{-1}$ of soil) in maize crop

\begin{tabular}{|c|c|c|c|c|c|c|}
\hline \multirow[b]{3}{*}{ Treatments } & \multicolumn{6}{|c|}{ Population count in different plant growth stages (cfu $\mathrm{g}^{-1}$ of soil) } \\
\hline & \multicolumn{2}{|c|}{30 DAS } & \multicolumn{2}{|c|}{60 DAS } & \multicolumn{2}{|c|}{90 DAS } \\
\hline & $\begin{array}{c}\text { Bacteria } \\
\text { x10 }^{7} \text { cfu }^{-1}\end{array}$ & $\begin{array}{c}\text { Fungi } \\
\times 10^{4} \mathrm{cfu} \mathrm{g}^{-1}\end{array}$ & $\begin{array}{c}\text { Bacteria } \\
\mathbf{x 1 0}^{7} \mathrm{cfu}^{-1}\end{array}$ & $\begin{array}{c}\text { Fungi } \\
\times 10^{4} \mathrm{cfu}^{-1}\end{array}$ & $\begin{array}{l}\text { Bacteria } \\
\text { x10 }^{7} \mathrm{cfu}^{-1}\end{array}$ & $\begin{array}{c}\text { Fungi } \\
\times 10^{4} \mathrm{cfu} \mathrm{g}^{-1}\end{array}$ \\
\hline Control & 4.76 & 4.28 & 6.13 & 6.16 & 4.13 & 4.06 \\
\hline $\mathrm{T}_{1}$ & 10.00 & 4.56 & 10.60 & 8.50 & 8.26 & 6.23 \\
\hline $\mathrm{T}_{2}$ & 10.70 & 4.32 & 10.90 & 8.33 & 8.73 & 6.13 \\
\hline $\mathrm{T}_{3}$ & 11.12 & 6.85 & 13.40 & 8.70 & 9.16 & 5.70 \\
\hline $\mathrm{T}_{4}$ & 9.86 & 5.64 & 10.20 & 7.50 & 7.20 & 5.23 \\
\hline $\mathrm{T}_{5}$ & 12.40 & 6.45 & 15.40 & 9.00 & 10.33 & 7.16 \\
\hline $\mathrm{T}_{6}$ & 13.32 & 7.45 & 16.40 & 10.40 & 10.50 & 8.20 \\
\hline $\mathrm{T}_{7}$ & 22.40 & 9.00 & 26.60 & 18.26 & 22.03 & 11.45 \\
\hline CD & 0.267 & 0.100 & 0.495 & 0.317 & 0.414 & 0.307 \\
\hline SE(d) & 0.125 & 0.047 & 0.232 & 0.148 & 0.194 & 0.143 \\
\hline SE (m) & 0.088 & 0.033 & 0.164 & 0.105 & 0.137 & 0.101 \\
\hline $\mathrm{CV}$ & 1.293 & 0.942 & 2.069 & 1.889 & 2.361 & 2.593 \\
\hline
\end{tabular}

Treatments:

Control: RDF.

$\mathrm{T}_{1}$ : Carrier based PSB biofertilizer.

$\mathrm{T}_{2}$ : Liquid PSB biofertilizer.

$\mathrm{T}_{3}$ : Biofilmed PSB biofertilizer.

$\mathrm{T}_{4}$ : Carrier based PSB biofertilizer + Liquid PSB biofertilizer.

$\mathrm{T}_{5}$ : Carrier based PSB biofertilizer + Biofilmed PSB biofertilizer.

$\mathrm{T}_{6}$ : Liquid PSB biofertilizer + Biofilmed PSB biofertilizer.

$\mathrm{T}_{7}$ : Carrier + Liquid + Biofilmed PSB biofertilizer.

Plate.1 Compatibility studies and development of different biofilms

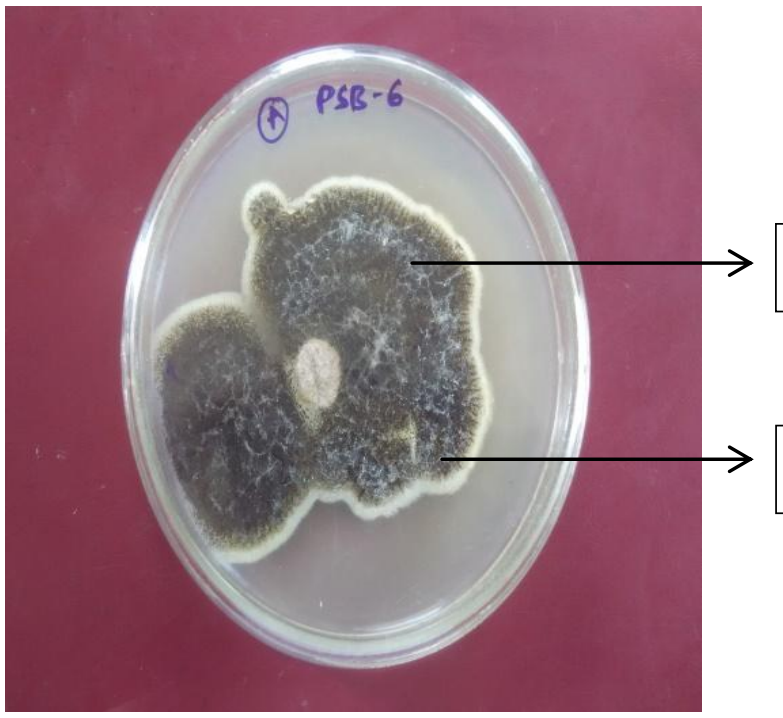

Compatibility of bacteria with fungi
PSB6 bacterial growth

Asp1 fungal growth 


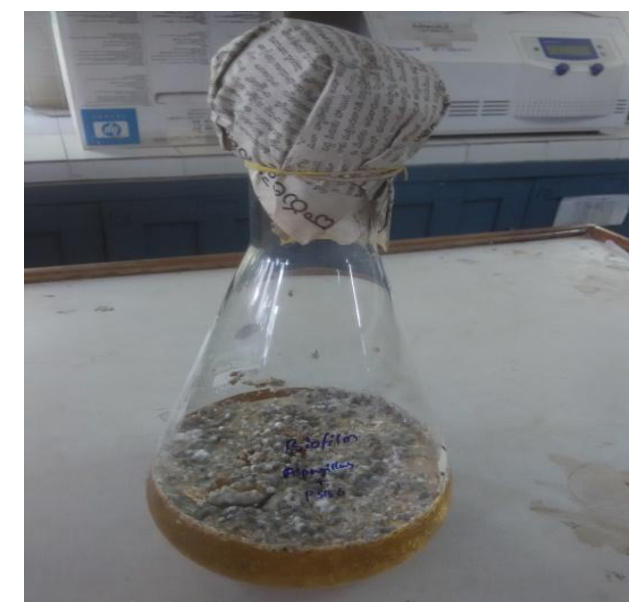

Bacillus spp - Aspergillus spp Biofilm in Pikovaskaya broth

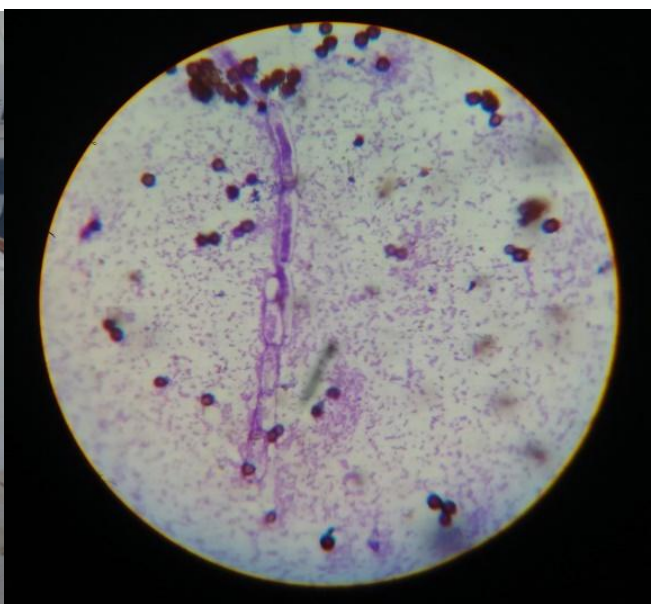

Microscopic observation of Bacillus spp and Aspergillus spp

Plate.2 Maize crop at different growth stages

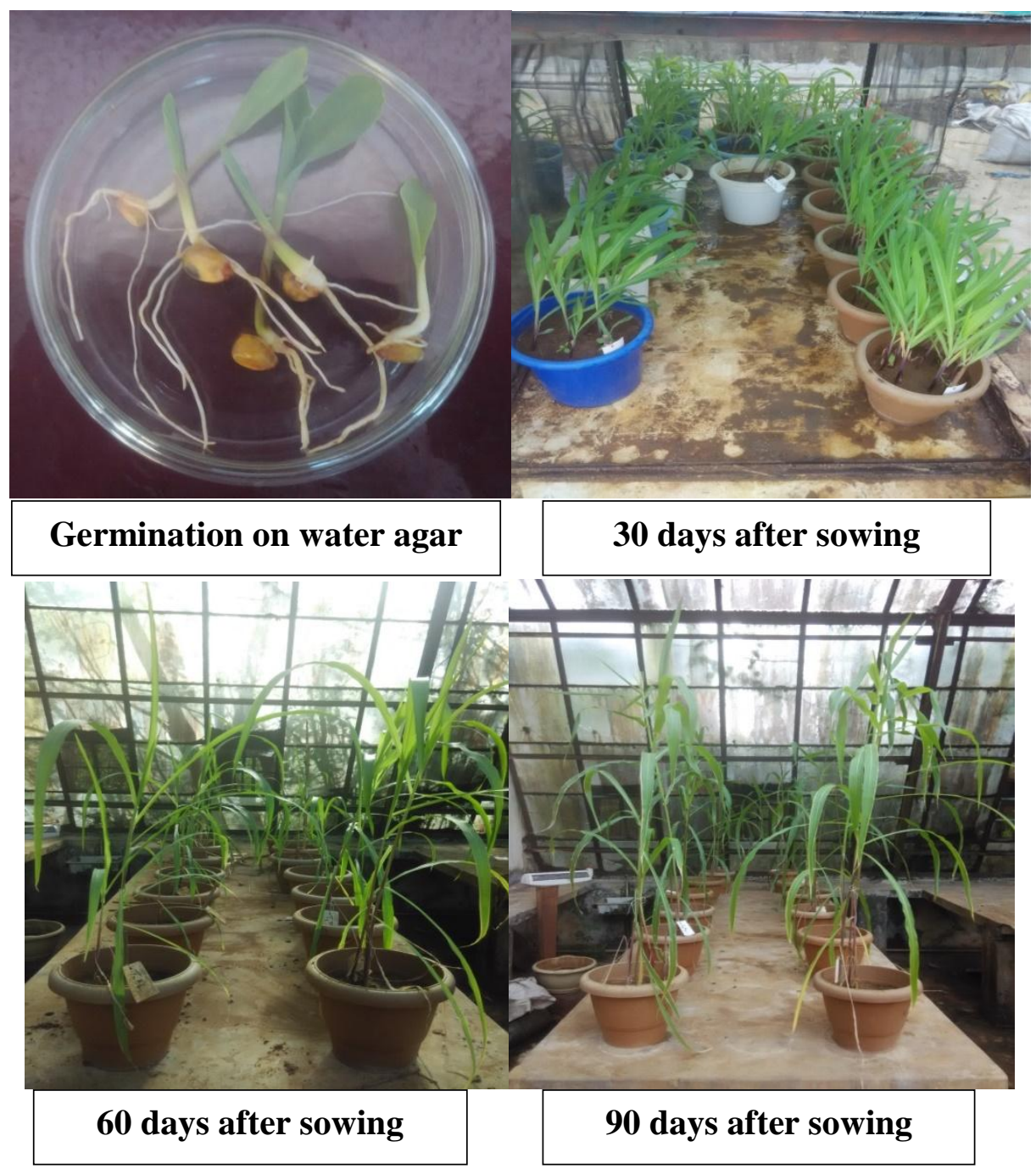




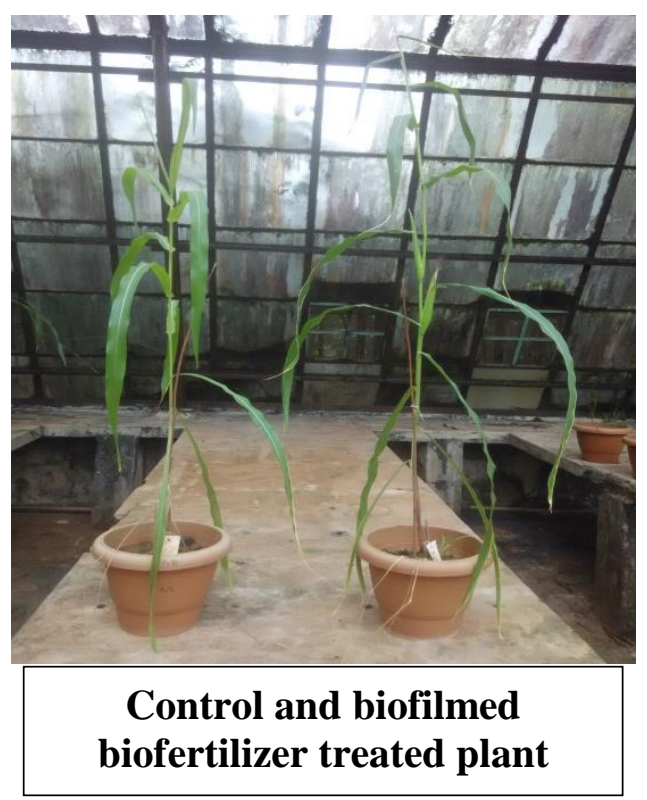

Compared to 30 days, after 60 days of sowing percentage of bacterial population was higher in $\mathrm{T}_{7}-$ Carrier + Liquid + Biofilmed PSB biofertilizer $(42.38 \%)$. The lowest bacterial population was observed in $_{4}$ - Carrier based PSB biofertilizer + Liquid PSB biofertilizer $(13.53 \%)$.

At 90 DAS bacterial population was highest in $\mathrm{T}_{7}-$ Carrier + Liquid + Biofilmed PSB biofertilizer $\left(22.03 \times 10^{7}\right)$. The lowest bacterial population was observed inT $_{4}$ Carrier based PSB biofertilizer + Liquid PSB biofertilizer $\left(7.20 \times 10^{7}\right)$.

After 90 days of sowing the percentage reduction in bacterial population was higher in $\mathrm{T}_{6^{-}}$Liquid PSB biofertilizer + Biofilmed PSB biofertilizer (52.38). The lowest decline in percentage bacterial population was observed in both $\mathrm{T}_{1}$ - Carrier based PSB biofertilizer and $\mathrm{T}_{2}$ - Liquid PSB biofertilizer $(30.81 \%)$.

At 30 DAS higher fungal population was observed in $\mathrm{T}_{7}-$ Carrier + Liquid + Biofilmed PSB biofertilizer $\left(9.00 \times 10^{4}\right)$. The lowest fungal population was observed in $\mathrm{T}_{2}$ - Liquid PSB biofertilizer $\left(4.32 \times 10^{4}\right)$.
After 30 days of sowing, percentage increase in fungal population compared to the initial culture population was higher in $\mathrm{T}_{7}$ - Carrier + Liquid + Biofilmed PSB biofertilizer (44.55 $\%)$.The lowest increased percentage of bacterial population was observed inT $_{2}$ Liquid PSB biofertilizer (9.41\%).

At 60 DAS highest fungal population was observed in $\mathrm{T}_{7}-$ Carrier + Liquid + Biofilmed PSB biofertilizer $\left(18.26 \times 10^{4}\right)$ and the lowest fungal population was observed in $\mathrm{T}_{4}$ - Carrier based PSB biofertilizer + Liquid PSB biofertilizer $\left(7.50 \times 10^{4}\right)$.

After 60 days of sowing increase in percentage of fungal population was higher in $\mathrm{T}_{7}$-Carrier + Liquid + Biofilmed PSB biofertilizer $(68.97 \%)$ compared to the 30 DAS. The lowest increase in bacterial population was observed inT $_{3}$ - Biofilmed PSB biofertilizer (29.96\%).

At 90 DAS highest fungal population was recorded in $\mathrm{T}_{7}-$ Carrier + Liquid + Biofilmed PSB biofertilizer $\left(11.45 \times 10^{4}\right)$ and lowest fungal population was observed in $\mathrm{T}_{4}$ - Carrier based PSB biofertilizer + Liquid PSB biofertilizer $\left(5.23 \times 10^{4}\right)$. 
After 90 days of sowing, fungal population decrease was maximum in was in $\mathrm{T}_{7}$ - Carrier + Liquid + Biofilmed PSB biofertilizer (55.56 $\%)$. The percentage decline in bacterial population was lowest in $\mathrm{T}_{5}$ - Carrier based PSB biofertilizer + Biofilmed PSB biofertilizer (48.33\%).

The persistence of population of bacteria and fungi is much higher in the biofilm preparation compared to individual cultures. The persistency was better in $\mathrm{T}_{7}-$ Carrier + Liquid + Biofilmed PSB biofertilizer followed by $\mathrm{T}_{6}$-Liquid PSB biofertilizer + Biofilmed PSB biofertilizer. This might be due to high indigenous population within the biofilm, increase in soil physical, chemical and biological properties of soil increased the levels of readily available nutrients, phytohormones, enzymes during crop growth stage. This study elucidated the synergistic effect of fungi and bacteria along with varying levels of nutrition which improved the persistency and growth of organisms.

Karthick et al., (2014) also reported on persistence and plant growth promoting effect of bioencapsulated formulation of suitable bacterial biofertilizers. The present investigation was supported by Triveni et al., (2013) who showed the persistence of Bacillus - Trichoderma viride biofilm in different formulations.

Maximum persistence of PSB was recorded in the treatment $\mathrm{T}_{7}$ (Carrier + Liquid+ Biofilmed PSB biofertilizer) at all the three growth stages. This study illustrated that the effective persistency of biofilmed biofertilizers influenced the crop in the form of increased growth, yield and soil nutrient management.

Based on the results obtained in the present study, it can be concluded that the biofilmed biofertilizers were more effective, highly responsive and more persistent under pot culture conditions when compared to individual cultures and control. The better ability of these biofilms was due to its higher PGPR activity, strongest interaction between bacteria and fungi and resistant to different environmental conditions which influenced the crop yields.

\section{References}

Dicho, A.H and Verma, R.K. 2014. Effect of growth promoting microbes on intial growth of maize. Indian Journal Tropical Biodiversity. 22(1): 64-69.

Karthick, R.N.S., Subha Lakshmi, S and Arvind Bharani, R.S. 2014. Evaluation of Persistence and Plant Growth Promoting effect of bioencapsulated formulation of suitable bacterial Biofertilizers. Biosciences Biotechnology Research Asia. 11 (2): 407-415.

Nissipaul, M., Triveni, S and Subhash Reddy, R. 2014. Thesis on study of biofilmedbiofertilizers to improve crop production and disease control in chickpea. PJTSAU, College Of Agriculture, Hyderabad.

Prasanna, R., Triveni, S., Bidyarani, N., Santosh Babu., Kuldeep Yadav., Anurup, A., Sangeeta, K., Madan Pal., Yashbir Singh Shivay and Anil Kumar Saxena. 2014. Evaluating the efficacy of cyanobacterial formulations and biofilmed inoculants for leguminous crops. Achieves of Agronomy and Soil Science. 60: 349-366.

Seneviratne, G. 2003. Development of ecofriendly, beneficial microbial biofilms. Current Sceince. 85: 1395-1396.

Singh, C.P and Amberger, A. 1998. Organic acid and phosphorus solubilisation in straw composted with rock phosphate. Bioresource Technology. 68: 13-16.

Triveni, S., Prasanna, R., Shukla, L and Saxena, A.K. 2013. Evaluating the 
biochemical traits of novel Trichoderma based biofilms for use as plant growth promoting inoculants. Annals of Microbiology. 63(3): 1147-1156.

Triveni, S., Radha Prasanna., Arun Kumar., Ngangom Bidyarani., Rajendra Singh and Kumar Saxena. 2015. Evaluating the promise of Trichoderma and Anabaena based biofilms as multifunctional agents in Macrophomina phaseolina infected cotton crop. Biocontrol Science and Technology. 25(6): 656-670.

Zahir, A., Arshad, Z.M and Frankenberger, W.F. 2004. Plant growth promoting rhizobacteria. Advances in Agronomy. 81: 97-168.

Zaidi, A and Mohammad, S. 2006. Coinoculation effects of phosphate solubilizing microorganisms and Glomus fasciculatum on green gram bradyrhizobium symbiosis. Agricultural Science. 30: 223-230.

\section{How to cite this article:}

Vinod Babu, S., S. Triveni, R. Subhash Reddy and Sathyanarayana, J. 2017. Persistence of PSB-Fungi Biofilmed Biofertilizer in the Soils and its Effect on Growth and Yield of Maize. Int.J.Curr.Microbiol.App.Sci. 6(12): 1812-1821. doi: https://doi.org/10.20546/ijcmas.2017.612.205 